\title{
Peran Gender dalam Pengelolaan Budidaya Tanaman Padi Pada Gapoktan Sumber Rejeki Desa Kalanganyar Kecamatan Karanggeneng Kabupaten Lamongan Jawa Timur
}

\author{
PUPUT DEWI PURNAMA, NI WAYAN SRI ASTITI, WAYAN SUDARTA
}

Program Studi Agribisnis, Fakultas Pertanian, Universitas Udayana

Jl. PB. Sudirman Denpasar 80323

Email: puput888819@gmail.com

wayansriastiti@yahoo.co.id

\begin{abstract}
Gender Roles in the Management of Rice Cultivation, A Case Study on The Farmers' Group of Sumber Rejeki at Kalanganyar Village, Karanggeneng Subdistrict, Lamongan Regency, East Java

Most women act as housewives, in addition to being active in household activities, rural women are also participating in rice farming activities from land-processing to harvesting. The study aimed to determine the role of gender in rice farming seen from three aspects, namely activity profile, access profile, and control profile (decision making). The research method used is survey method with interview approach. Data analysis was conducted descriptivelywith qualitative and quantitative methods. The findings showed that the role of women and men is different in every farming activity. (A) The profile of activity in the outpouring of male labor is greater than that of women, the average outpouring of male domestic labor is 199.16 hours per cultivating season and women is 123.41 hours per season with an average land area of 6, 64 ares. (B) In the access profile, men have greater access of $78.06 \%$ while women of $21.94 \%$, . (C) The women's participation control profile is very low compared with men, it means that the pattern of decision making is dominated by men up to $96.08 \%$. Based on the results of research, it can be suggested that women should play an active role in productive and non productive work. Men are advised also to assist in the housework to relieve women's work so that the housework is not neglected. It is also expected to involve women in the extension so that they can increase participation in their farming activities.
\end{abstract}

Keywords: gender roles, rice cultivation, farmers group of Sumber Rejeki

\section{Pendahuluan}

\subsection{Latar Belakang}

Peran gender adalah peran yang diciptakan oleh masyarakat bagi laki-laki dan perempuan. Laki-laki diharapkan melakukan peran yang bersifat instrumental atau berorientasi pada pekerjaan untuk memperoleh nafkah, sedangkan perempuan melakukan peran yang bersifat ekspresif yang berorientasi pada emosi manusia 
(Megawangi 1999). Dinyatakan oleh Mugniesyah (2006) bahwa perbedaan jenis kelamin telah mempengaruhi manusia untuk memberi persepsi identitas peranan gender atau mengakibatkan perbedaan peranan gender. Perbedaan biologis seringkali menjadi landasan masyarakat untuk mengkotakkan peran perempuan dan laki-laki.

Sudarta (2010) menyatakan bahwa peranan perempuan di sektor pertanian adalah sesuatu yang tidak terbantahkan. Usahatani tanaman pangan, pembagian kerja antara pria dan wanita sangat jelas terlihat, sering dikatakan bahwa pria bekerja untuk kegiatan yang banyak menggunakan otot dan wanita bekerja untuk kegiatan yang banyak memakan waktu. Oleh karenanya, akses wanita yang lebih baik terhadap sumberdaya melalui program pemerintah juga memberikan kesempatan kepada wanita untuk berkontribusi lebih besar dalam kegiatan ekonomi produktif.

Darsono (2005) menyatakan bahwa, di perdesaan wanita harus bekerja jauh lebih panjang dari pada pria di bidang pertanian, wanita mempunyai tugas sebagai, menanam tanaman, serta membersihkan rumput penggangu tanaman. Pria mengatur hasil panen dan menjaga tanaman. Begitu pula halnya di Gapoktan Sumber Rejeki Desa Kalanganyar, Kecamatan Karanggeneng Kabupaten Lamongan, wanita lebih berperan dalam kegiantan budidaya tanaman padi. Wanita di Desa Kalanganyar banyak melakukan kegiatan budidaya tanaman padi seperti mencabut bibit, menanam bibit, menyiangan, dan panen.

Berdasarkan uraian di atas, maka menarik bagi penulis untuk diadakan penelitian tentang "Peran Gender dalam Pengelolaan Usahatani Padi di Desa Kalanganyar, Kecamatan Karanggeneng, Kabupaten Lamongan”.

\subsection{Rumusan Masalah}

Berdasarkan uraian di atas, maka rumusan masalah untuk penelitian ini, bagaimana peran gender dalam pengelolaan budidaya tanaman padi, dilihat dari segi berikut.

1. Bagaimana profil aktivitas pria dan wanita dalam budidaya tanaman padi pada Gapoktan Sumber Rejeki Desa Kalanganyar, Kecamatan Karanggeneng, Kabupaten Lamongan?

2. Bagaimana profil akses pria dan wanita dalam budidaya tanaman padi pada Gapoktan Sumber Rejeki Desa Kalanganyar, Kecamatan Karanggeneng, Kabupaten Lamongan?

3. Bagaimana profil kontrol (pengambilan keputusan) pria dan wanita dalam budidaya tanaman padi pada Gapoktan Sumber Rejeki Desa Kalanganyar, Kecamatan Karanggeneng, Kabupaten Lamongan?

\subsection{Tujuan Penelitian}

Penelitian ini bertujuan untuk mengetahui peran gender dalam pengelolaan usahatani padi dilihat dari tiga aspek berikut. 
1. Profil aktivitas pria dan wanita dalam budidaya tanaman padi pada Gapoktan Sumber Rejeki Desa Kalanganyar, Kecamatan Karanggeneng, Kabupaten Lamongan.

2. Profil akses pria dan wanita dalam budidaya tanaman padi pada Gapoktan Sumber Rejeki Desa Kalanganyar, Kecamatan Karanggeneng, Kabupaten Lamongan.

3. Profil kontrol (pengambilan keputusan) pria dan wanita dalam budidaya tanaman padi pada Gapoktan Sumber Rejeki Desa Kalanganyar, Kecamatan Karanggeneng, Kabupaten Lamongan.

\section{Metode Penelitian}

\subsection{Lokasi dan Waktu Penelitian}

Penelitian ini dilakukan di Kabupaten Lamongan yaitu Gapoktan Sumber Rejeki, Desa Kalanganyar, Kecamatan Karanggeneng. Pemilihan lokasi ini dilakukan secara purposive sampling, yaitu suatu metode penentuan lokasi penelitian secara sengaja berdasarkan pertimbangan tertentu. Penelitian ini diselesaikan dalam waktu 3 bulan, mulai bulan Mei hingga Agustus 2016.

\subsection{Sumber dan Jenis Data}

Sumber data dalam penelitian ini meliputi data primer dan data sekunder. Jenis data terdiri atas data kualitatif dan data kuantitatif. Data primer diperoleh hasil wawancara langsung dengan responden menggunakan kuisioner. Informasi langsung dari Ketua Gapoktan Sumber Rejeki mengenai peran gender dalam pengelolaan budidaya tanaman padi. Dokumentasi berupa foto-foto kegiatan wawancara dengan Ketua Gapoktan dan responden. Data sekunder meliputi studi kepustakaan, seperti berupa laporan-laporan, dokumen, situs internet, jurnal, dan data dari instansi terkait dengan gapoktan. Data kualitatif menjelaskan mengenai peran gender dalam pengelolaan budidaya tanaman padi anggota Gapoktan Sumber Rejeki Desa Kalanganyar. Data kuantitatif berupa hasil rekapitulasi data curahan tenaga kerja dan jumlah anggota rumah tangga gapokta.

\subsection{Pengumpulan Data}

Adapun teknik pengumpulan data yang digunakan dalam penelitian ini adalah metode survei dengan wawancara dan dokumentasi.

\subsection{Populasi dan Sampel (Responden)}

Populasi dalam penelitian ini adalah semua anggota Gapoktan Sumber Rejeki Desa Kalanganyar yang aktif. Anggota gapoktan berjumlah 106 orang yang aktif dalam kegiatan budidaya tanaman padi.

Menurut Sevilla (1993), semakin kecil toleransi kesalahan, semakin akurat sampel menggambarkan populasi. Peneliti menentukan batas kesalahan $10 \%$ berarti memiliki tingkat akurasi 90\%. Berdasarkan data jumlah keseluruhan anggota 
gapoktan sumber rejeki sebanyak 106 orang. Penggunakan rumus Slovin, pertama menentukan beberapa batas toleransi kesalahan. Batas toleransi kesalahan ini dinyatakan dengan presentase. Jumlah sampel yang diperoleh berdasarkan rumus di atas adalah sebanyak 51 anggota. Jumlah responden yang diperoleh sebesar 51 anggota.

\subsection{Analisis Data}

Data yang terkumpul dan dikelompokkan kedalam masing-masing indikator maka data tersebut ditabulasi dari kuisioner ke kerangka tabel. Untuk mengetahui bagaimana peran gender dalam pengelolaan usahatani padi, data akan dianalisis secara deskriptif. Tahap profil aktivitas diukur dengan curahan tenaga kerja (jam) pria dan wanita.

Profil akses diukur terhadap sumberdaya produktif antara pria dan wanita. Profil kontrol (pengambilan keputusan) dalam pengelolaan usahatani padi dilihat dari pengambilan keputusan yang dianalisis dengan lima tipe pengambilan keputusan menurut Sajogyo (1983) yaitu (1) pengambilan keputusan oleh istri sendiri, (2) bersama tetapi pengaruh istri lebih dominan, (3) bersama setara, (4) bersama tetapi pengaruh suami lebih dominan (5) pengambilan keputusan oleh suami sendiri.

\section{Hasil dan Pembahasan}

\subsection{Profil Aktivitas Pria dan Wanita dalam Pengelolaan Budidaya Tanaman Padi}

Menurut Handayani (2001), profil aktifitas adalah mengumpulkan data mengenai apa yang sebenarnya dikerjakan oleh laki-laki dan perempuan. Pembagian pekerjaan dalam kegiatan usahatani siapa yang mengerjakan apa dalam kegiatan masyarakat. Tabel 1 menunjukkan bahwa pada tahap persemaian pria memiliki ratarata curahan tenaga kerja dalam semusim lebih besar sebesar 4,53 jam dalam semusim, dan wanita sebesar 2,80 jam dalam semusim.

Tabel 1 menunjukkan bahwa tahap pengolahan tanah pria memiliki rata-rata curahan tenaga kerja sebesar 26,51 jam dalam semusim, dan curahan tenga kerja wanita memiliki rata-rata 3,94 jam dalam semusim. Tahap pengolahan tanah dimana wanita tidak memiliki curahan jam kerja adalah pada saat pencangkulan, pembajakan dan penggaruan. Hal ini disebabkan pencangkulan merupakan pekerjaan yang berat sehingga wanita dianggap tidak mampu melakukannya, di samping itu pembajakan biasanya dilakukan oleh pria.

Curahan tenaga kerja pada tahap pencabutan dan penanaman bibit rata-rata curahan tenaga pria adalah 5,98 jam dan rata-rata curahan tenaga kerja wanita sebesar 7,71 jam hal ini dikarenakan di daerah tersebut pada saat penanaman bibit wanita desa membuat kelompok kecil yang terdiri atas lima orang, sehingga curahan tenaga kerja wanita memiliki rata-rata paling tinggi. 


\section{Tabel 1.}

Rata-rata Curahan Tenaga Kerja Pria dan Wanita, dalam dan luar Rumah Tangga dalam pengelolaan budidaya tanaman padi sendiri dalam semusim pada Gapoktan

Sumber Rejeki, 2016

\begin{tabular}{|c|c|c|}
\hline \multirow{3}{*}{ jenis kegiatan } & \multicolumn{2}{|c|}{ Rata-rata Curahan Tenaga Kerja } \\
\hline & Pria & Wanita \\
\hline & Dalam RT & Dalam RT \\
\hline Persemaian & 4,53 & 2,80 \\
\hline Jumlah & 4,53 & 2,80 \\
\hline \multicolumn{3}{|l|}{ Pengolahan tanah } \\
\hline a. Pembersihan & 7,24 & 3,94 \\
\hline b. Pencangkulan & 6,76 & 0,00 \\
\hline c. Pembajakan & 6,75 & 0,00 \\
\hline d. Penggaruan & 5,76 & 0,00 \\
\hline Jumlah & 26,51 & 3,94 \\
\hline Pencabutan dan penanaman bibit & 5,98 & 7,71 \\
\hline Jumlah & 5,98 & 7,71 \\
\hline \multicolumn{3}{|l|}{ Pemeliharaan } \\
\hline a. pengairan & 25,98 & 0,00 \\
\hline b. Penyiangan & 9,27 & 6,51 \\
\hline c. Pemupukan & 12,75 & 0,00 \\
\hline d. Pengendalian hama dan penyakit & 20,63 & 0,00 \\
\hline $\begin{array}{r}\text { Jumlah } \\
\end{array}$ & 68,63 & 6,51 \\
\hline Panen dan pengangkutan & 15,45 & 15,29 \\
\hline Jumlah & 15,45 & 15,29 \\
\hline \multicolumn{3}{|l|}{ Pasca panen } \\
\hline a. Penjemuran/penyimpanan & 75,61 & 85,96 \\
\hline b. Penjualan hasil & 2,45 & 1,20 \\
\hline Jumlah & 78,06 & 87,16 \\
\hline Total & 199,16 & 123,41 \\
\hline
\end{tabular}

Curahan tenaga kerja pada tahap pemeliharaan pria memiliki rata-rata curahan tenaga kerja 68,63 jam dalam semusim. Tenaga kerja wanita memiliki rata-rata curahan tenagga kerja sebesar 6,51, hal ini dikarenakan pada saat pengairan petani harus menghidupkan diesel yang tidak dapat dilakukan oleh wanita, sedangkan pada tahap pemupukan wanita tidak mampu mengangkat pupuk dalam karung menuju ke lokasi sawah begitu pula pada saat pengendalian hama dan penyakit pria harus memanggul alat penyemprot hama yang berat sehingga wanita tidak mampu untuk melakukannya.

Tahap panen dan pengangkutan pria memiliki rata-rata curahan tenaga kerja sebesar 15,45 jam dalam semusim hal ini dikarenakan dalam panen membutuhkan banyak tenaga kerja pria untuk memotong dan merontokkan padi. Wanita memiliki curahan tenaga kerja sebesar 15,29 jam dalam semusim, pada saat panen ini tenaga 
kerja wanita luar rumah tangga biasanya datang sendiri untuk membantu memotong padi pemilik maupun penggarap lahan dengan sistem pemberian gabah seikhlasnya dari pemilik maupun penggarap lahan, para tenaga kerja luar rumah tangga ini biasanya disebut "pencari gabah". Sedangkan pengangkutan sudah dilakukan pula oleh para tenaga kerja pria biasanya mereka mengangkut menggunakan sepeda ontel maupun sepeda motor yang mereka miliki.

Pada tahap penjemuran/penyimpanan pria memiliki curahan tenaga kerja ratarata 75,61 jam dalam semusim, sedangkan rata-rata curahan tenaga kerja wanita sebesar 85,96 jam dalam semusim, hal ini dikarenakan dalam menjaga padi pria tidak bisa melakukannya setiap saat karena pria memiliki kesibukan lain seperti mengambil rumput dan sebagainya. Pada tahap pejualan hasil pria memiliki curahan tenaga kerja rata-rata 2,45 jam dan wanita memiliki rata-rata curahan tenaga kerja 1,20 jam dalam semusim hal ini dikarenakan pria lebih dominan dalam menentukan harga dibanding wanita.

Mengacu pada hasil penelitian maka dapat dilihat bahwa pada pelaksanaan budidaya tanaman padi pria memiliki pertisipasi yang sangat besar. Pria memiliki curahan tenaga kerja yang lebih besar dari pada wanita yaitu masing-masing sebesar 199,16 dan 123,41 jam dalam semusim.

Pelaksanaan budidaya tanaman padi ini melibatkan wanita tetapi tidak pada semua kegiatan dikarenakan peran utama seorang wanita adalah mengatur rumah tangga dengan melakukan tugas-tugas rumah tangga seoerti memasak, mengurus anak, dan lain sebagainya. Biasanya wanita menyiapkan dan menyelesaikan pekerjaan-pekerjaan rumah tangga terlebih dahulu baru kemudian mereka pergi ke sawah, artinya wanita melakukan fungsi yang ganda baik pengatur rumah tangga maupun sebagai pencari nafkah.

\subsection{Profil Akses Pria dan Wanita}

Menurut Puspitawati (2012), Aspek Akses diartikan sebagai kapasitas untuk menggunakan sumberdaya untuk sepenuhnya berpartisipasi secara aktif dan produktif dalam masyarakat termasuk akses terhadap sumberdaya, dan informasi.

Profil akses suami dan istri dalam rumah tangga responden terdiri atas lahan pertanian (sawah dan tegalan), lahan non pertanian (pekarangan dan bangunan), peralatan pertanian, tenaga kerja, kapital/kredit, peyuluhan pertanian, pengelolaan/pemanfaatan hasil pertanian (sawah). Profil akses dalam rumah tangga responden adalah pria lebih dominan sebesar $68,61 \%$ dari pada wanita sebesar sebesar 31,38\%. Profil akses pria dan wanita rumah tangga responden dapat dilihat pada Tabel 2. 


\section{Tabel 2.}

Profil Akses Pria dan Wanita terhadap Sumberdaya Produktif dalam Rumah Tangga Responden di Gapoktan Sumber Rejeki, Tahun 2016

\begin{tabular}{llcc}
\hline \multirow{2}{*}{ No } & \multicolumn{1}{c}{ Uraian } & \multicolumn{2}{c}{ Akses (\%) } \\
\cline { 3 - 4 } & & Pria & Wanita \\
\hline 1. & Lahan Pertanian Sawah & 100 & 0 \\
2. & Lahan Non Pertanian (pekarangan dan & 74,51 & 25,49 \\
& bangunan) & & \\
3. & Peralatan pertanian & 100 & 0 \\
4. & Tenaga kerja & 100 & 92,16 \\
5. & Kapital/kredit & 100 & 0 \\
6. & Penyuluhan pertanian & 100 & 0 \\
7. & Aktivitas sosial & 100 & 94,11 \\
& Pengelolaan/pemanfaatan hasil pertanian & & \\
8 & (sawah) & 100 & 100 \\
9 & Penjualan Hasil $\quad$ Total & 100 & 88,23 \\
\hline & $\quad$ Persen & 874,51 & 399,99 \\
\hline
\end{tabular}

Tabel 2 wanita tidak mempunyai akses terhadap lahan sawah, peralatan pertanian, kapital/kredit, dan penyuluhan pertanian. Akses terhadap lahan sawah di daerah penelitian dalam hal waris laki-laki dan perempuan memiliki kesempatan yang sama, perbedaan porsi pembagian waris bagi laki-laki akan mendapatkan bagian kramanan dalam bahasa jawa berarti lahan sawah dan perempuan mendapatkan bagian pekarangan dan bangunan (25,49\%), sebagian besar masih menganut sistem kekerabatan bilateral. Dinyatakan oleh Van Dijk (2006) bilateral adalah anak menghubungkan diri dengan orang tuanya, anak juga menghubungkan diri dengan kerabatayah dan ibunya secara bilateral. Sistem kekerabatan bilateral kedua orang tua maupun kerabat dari ayah ibunya berlaku peraturan yang sama baik tentang perkawinan, kewajiban memberi nafkah, penghormatan dan warisan.

\subsection{Profil Kontrol (Pengambilan Keputusan) dalam Pengelolaan Budidaya Tanaman Padi}

Dinyatakan oleh J. Reason (1990) pengambilan keputusan atau kontrol dapat dianggap sebagai suatu hasil atau keluaran dari proses mental atau kognitif yang membawa pada pemilihan satu jalur tindakan di antara beberapa alternatif yang tersedia. Profil kontrol (pengambilan keputusan) pada budidaya tanaman padi dapat dilihat mulai dari pembuatan persemaian, pengelolaan tanah, pencabutan dan penanaman bibit, pemeliharaan, pembelian sarana produksi, investasi dalam bentuk alat produksi, penetapan tenaga kerja, panen dan pengankutan, dan penggunaan hasil. Pengambilan keputusan dalam pengelolaan budidaya tanaman padi didominasi oleh 
pria. wanita memiliki profil kontrol (pengambilan keputusan) oleh rumah tangga responden dalam pengelolaan budidaya tanaman padi dapat dilihat pada tabel 3 .

Tabel 3.

Rata-rata Pengambilan Keputusan dalam Pengelolaan Budidaya Tanaman Padi Pada Gapoktan Sumber Rejeki Desa Kalanganyar

\begin{tabular}{|c|c|c|c|c|c|c|}
\hline \multirow[b]{2}{*}{ No } & \multirow[b]{2}{*}{$\begin{array}{c}\text { Kontrol (pengambilan } \\
\text { keputusan }\end{array}$} & \multicolumn{5}{|c|}{ pengambilan keputusan (persen) } \\
\hline & & $\begin{array}{c}\text { istri } \\
\text { sendiri }\end{array}$ & $\begin{array}{c}\text { bersama } \\
\text { tetapi } \\
\text { pengaruh } \\
\text { istri lebih } \\
\text { dominan }\end{array}$ & $\begin{array}{c}\text { bersama } \\
\text { setara }\end{array}$ & $\begin{array}{c}\text { bersama } \\
\text { tetapi } \\
\text { pengaruh } \\
\text { suami lebih } \\
\text { dominan }\end{array}$ & $\begin{array}{l}\text { suami } \\
\text { sendiri }\end{array}$ \\
\hline 1 & Pembuatan persemaian & 0,00 & 0,00 & 0,00 & 3,92 & 96,08 \\
\hline 2 & Pengolahan tanah & 0,00 & 0,00 & 0,00 & 11,76 & 88,24 \\
\hline 3 & pencabutan dann & & & & & \\
\hline & penanaman bibit & 0,00 & 0,00 & 62,75 & 23,53 & 13,73 \\
\hline 4 & Pemeliharaan & 0,00 & & & & \\
\hline & a. Pengairan & 0,00 & 0,00 & 0,00 & 17,65 & 82,35 \\
\hline & b. Penyiangan & 0,00 & 54,90 & 19,61 & 13,73 & 11,76 \\
\hline & c. Pemupukan & 0,00 & 0,00 & 0,00 & 86,27 & 13,73 \\
\hline & $\begin{array}{l}\text { d.Pengendalian } \\
\text { hama/penyakit }\end{array}$ & 0,00 & 0,00 & 9,80 & 11,76 & $\mathbf{7 8 , 4 3}$ \\
\hline 5 & $\begin{array}{l}\text { Pembelian sarana } \\
\text { produksi }\end{array}$ & & & & & \\
\hline & a. Benih & 0,00 & 0,00 & 0,00 & 19,61 & 80,39 \\
\hline & b. Pupuk & 0,00 & 0,00 & 0,00 & 31,37 & 68,63 \\
\hline & c. Pestisida & 0,00 & 0,00 & 0,00 & 21,57 & $\mathbf{7 8 , 4 3}$ \\
\hline 6 & $\begin{array}{l}\text { Investasi dalam bentuk } \\
\text { alat produksi }\end{array}$ & 0,00 & 0,00 & 19,61 & 27,45 & 52,94 \\
\hline 7 & Penetapan tenaga kerja & 0,00 & 0,00 & 0,00 & 39,22 & 60,78 \\
\hline 8 & $\begin{array}{ll}\text { Panen } & \text { dan } \\
\text { pengangkutan } & \end{array}$ & 0,00 & 0,00 & 29,41 & 1,96 & 68,63 \\
\hline 9 & Penggunaan hasil & 0,00 & 17,65 & 72,55 & 9,80 & 0,00 \\
\hline
\end{tabular}

Hasil penelitian di lapangan menunjukkan partisipasi wanita lebih kecil dari pada partisipasi pria dalam hal pengambilan keputusan. Pada tahap pengelolaan usahatani padi dalam semusim istri mengambil keputusan sendiri tanpa pengaruh dari suami adalah 0 (nol). Hal ini menunjukkan bahwa petani wanita ketika mengambil keputusan dalam pengelolaan budidaya tanaman padi tidak memiliki kewenangan atau pengaruh yang kuat.

Istri yang mengambil keputusan bersama dengan suami tetapi istri yang lebih dominan, dapat dilihat pada tahap pemeliharaan pada proses penyiangan istri yang mendominasi keputusan dalam pengelolaan budidaya tanaman padi sebesar 54,90\%. Prosesnya adalah suami dan istri berunding bersama tentang rencana-rencana usahatani dan pada akhirnya istri yang mengambil keputusan. 
Istri yang mengambil keputusan bersama-sama dengan suami tanpa adanya dominasi dari istri maupun suami dapat dilihat pada tahap kegiatan penggunaan hasil sebesar 72,55\%. Keputusan yang diambil dengan cara ini membuat petani wanita diikutsertakan dalam pengambilan keputusan.

Bersama tetapi didominasi oleh suami dalam pengambilan keputusan dapat dilihat pada tahap pemeliharaan (pemupukan) sebesar $86,27 \%$, pengambilan keputusan dengan cara ini memberi peluang bagi istri untuk memberikan pemikiaran dalam pengelolaan budidaya tanaman padi. Akan tetapi walaupun istri diberi peluang namun keputusan tetap diambil oleh suami.

Pengambilan keputusan yang hanya dilakukan oleh suami dapat dilihat pada tahap pembuatan persemaian sebesar 96,08\%. Pengambilan keputusan pada tahap ini adalah presentase paling tinggi dibandingkan dengan presentase tahap yang lain.

Besarnya presentase keputusan yang didominasi pria menunjukkan bahwa petani wanita tidak banyak memberikan pemikiran yang bisa dipakai atau digunakan dalam pengelolaan budidaya tanaman padi. Walaupun ada keputusan bersama namun pada dasarnya pria tetap sebagai penentu keputusan, hal ini dikarenakan petani wanita tidak dilibatkan saat ada rapat anggota gapoktan sehingga mereka tidak banyak mengetahui tentang varietas tanaman, obat untuk pengendalian hama dan penyakit yang akan digunaka dan sebagainya.

\section{Simpulan dan Saran}

\subsection{Simpulan}

Berdasarkan hasil penelitian, maka peran gender dalam pengelolaan bedidaya tanaman padi di Gapoktan Sumber Rejeki, Desa Kalanganyar, Kecamatan Karanggeneng, Kabupaten Lamongan, Jawa Timur.

1. Peran gender dalam pengelolaan budidaya tanaman padi, dilihat dari profil aktivitas pria dan wanita. Hal ini terlihat dari rata-rata curahan tenaga kerja pria lebih besar dibanding wanita sebesar 199,16 jam dalam semusim dan rata-rata jumlah tenaga kerja wanita dalam rumah tangga sebesar 123,41 jam dalam semusim.

2. Peran gender dalam pengelolaan budidaya tanaman padi, dilihat dari profil akses pria dan wanita. Pria memiliki akses lebih dominan sebesar $78.06 \%$ dari wanita sebesar $21,94 \%$, hal ini dikarenakan masyarakat yang masih menganut sistem kekerabatan bilateral.

3. Peran gender dalam pengelolaan usahatani padi, dilihat dari profil kontrol (pengambilan keputusan) pria dan wanita. Tahap kegiatan budidaya tanaman padi pola pengambilan keputusan oleh suami sendiri pada tahap pembuatan persemaian sebesar 96,08\%. Pengambilan keputusan bersama tetapi pengaruh istri dominan pada tahap pemeliharaan (penyiangan) sebesar 54,90\%. Pengambilan keputusan bersama setara dapat dilihat dalam kegiatan penggunaan hasil $72,55 \%$. Pengambilan keputusan bersama tetapi pengaruh suami lebih dominan dalam hal pemeliharaan (pemupukan) sebesar 86,27\%. 


\subsection{Saran}

Berdasarkan hasil penelitian ini dapat disarankan bahwa sebaiknya wanita berperan aktif dalam pekerjaan produktif dan pekerjaan non produktif, selama pekerjaan rumah tangga tidak terabaikan dan pria turut membantu pelaksanaan pekerjaan rumah tangga yang dapat meringankan pekerjaan wanita serta penyuluhan yang dilaksanakan di Gapoktan Sumber Rejeki melibatkan wanita sehingga wanita mendapat informasi yang baik agar wanita bisa meningkatkan partisipasinya terutama dalam kegiatan budidaya tanaman padi.

\section{Ucapan Terima Kasih}

Terima kasih kepada ketua Gapoktan Sumber Rejeki Desa Kalanganyar, Kecamatan Karanggeneng, Kabupaten Lamongan, Jawa Timur yang telah memberikan data dalam penyelesaian penelitian dan penulisan e-jurnal ini. Semoga penelitian ini bermanfaat sebagaimana mestinya.

\section{Daftar Pustaka}

Darsono. 2005. Sosiologi Pedesaan. UMM Press Malang.

Handayani, 2008. Konsep dan Teknik Penelitian Gender. UMM Malang.

Mugniesyah, Siti Sugiah dan Mizuno Kosuke. 2007. “ Access to Land in Sundanese

Community: A Case Study of Upland Peasant Households in Kemang Village,

West Java, Indonesia. Southeast Asian Studies, vol. 44, no. 4, March.

Megawangi, R. 1999. Membiarkan Berbeda? Sudut Pandang Baru Relasi Gender.

Mizan Pustaka, Bandung.

Puspitawati, H. 2012. Gender dan Keluarga: Konsep dan Realita di Indonesia. PT

IPB Press. Bogor.

Reason, James. 1990. Human Eror. Ashgate. ISBN

Sajogyo, 1983. Peranan Wanita dalam Perkembangan Masyarakat Desa.

Diterbitkan untuk Yayasan Ilmu-ilmu Sosial. CV Rajawali. Jakarta.

Sevilla, dkk. 1993. Pengantar Metode Penelitian. Universitas Indonesia. Jakarta.

Sudarta, W. 2010. Peran Wanita dalam Pembangunan Berwawasan Gender. Jurusan

Sosial Ekonomi Pertanian, Fakultas Pertanian Universitas Udayana. Bali. www.pswunud.go.id. Diakses pada tanggal 25 januari 2016

Van Djik, 2006, Pengantar Hukum Adat Indonesia, Mundur majum Banding. 